\title{
Nursing approaches in the postoperative pain management
}

\author{
Ameliyat sonrası ağrı yönetiminde hemşirelik yakıaşımları
}

\author{
Sevilay Yüceer \\ Gazi University Faculty of Health Science Surgical Nursing Department, Ankara, Turkey
}

\begin{abstract}
Patients frequently experience moderate to severe pain in the postoperative period. Although the pain management is an integral and important part of the nursing care, studies suggest that, nursing management of postoperative pain remains inadequate.

Postoperative care nurses are responsible to assess the patient's pain, teach the patient strategies to deal with the pain, apply the analgesic treatment plan, monitor the results of treatment, educate the patient and the family on pain management and document the pain management outcomes. The nurses' holistic approach to pain management minimizes the patients' discomfort caused by pain in the postoperative period after the surgery. In this article, nurses' approaches to postoperative pain management are discussed. J Clin Exp Invest 2011; 2 (4): 474-478
\end{abstract}

Key words: Postoperative pain, pain management, nurse

\section{EFFECTS AND MECHANISMS OF THE PAIN}

Patients frequently experience moderate to severe pain following surgery. ${ }^{1,2}$ Despite this fact, measures to treat pain remain inadequate and large number of patients experience uncontrolled pain. Pain causes diminished quality of life, prolongs hospital stay, and increase morbidity and mortality. ${ }^{3}$

The negative effect of pain on quality of life emphasizes the importance of pain relief. International health organizations assume pain as a symptom of a disease, and point out its important role in determining prognosis of the disease. Pain can be a symptom of a disease (i.e. Crohn's disease, gallbladder disease); it can be a sign of disease progression (i.e. angina); or it can be a disease in itself (i.e. Complex Regional Pain Syndromes). The Joint Commission International $(\mathrm{JCl})^{4}$ and American Pain Society ${ }^{5}$ have suggested pain as the 5th vital sign, because mismanaged pain affects the patient's

\section{ÖZET}

Ameliyat sonrası dönemde hastalar sık sık orta ve şiddetli düzeyde ağrı deneyimlemektedir. Ağrı yönetiminin hemşirelik bakımının ayrılmaz ve önemli bir parçası olmasına rağmen yapılan çalışmalar ameliyat sonrası ağrı yönetiminin yetersiz olduğunu göstermektedir.

Ameliyat sonrası dönemde hemşire, ağrı değerlendirmesinden, ağrı ile başa çıkma yöntemlerinin hastaya öğretilmesinden, analjezi tedavi planının uygulanmasından, tedavi sonuçlarının izlenmesinden, hasta ve ailesinin ağrı yönetimi konusunda eğitilmesinden ve bu aşamaların kayıt edilmesinden sorumludur. Hemşirenin ağrı yönetimindeki bütüncül yaklaşımı hastanın ameliyat sonrasındaki rahatsızlığını en aza indirmektedir. Bu makalede hemşirenin ameliyat sonrası ağıı yönetimindeki yaklaşımları tartışılmıştır.

Anahtar kelimeler: Postoperatif ağrı, ağrı yönetimi, hemşire

health just like any other uncontrolled vital function in the postoperative period. ${ }^{6,7}$

Surgical tissue damage causes pain which in turn precipitates a stress chain reaction affecting the other organ systems. Uncontrolled pain may cause pulmonary complications secondary to muscle spasm and suppression of effective coughing, which leads to diminished vital capacity and inability to clear secretions with consequent risk of pneumonia. Severe pain prevents early ambulation and increases the risk of venous thromboembolism due to immobility. Pain also activates the sympathetic system and causes increased vascular resistance, increased myocardial oxygen consumption and cardiac overload due to catecholamine release, which in turn leads to increased blood pressure, altered cardiac output, and myocardial infarction. Catecholamine release results in compromised circulation, and consequently increases the risk of deep venous thromboses. It also causes constipation and 
urinary retention by decreasing gastrointestinal and splanchnic blood flow. ${ }^{8-10}$

Whereas inadequate control of pain may cause the effects mentioned above, excessive or improper use of the pain medications may lead to other complications by causing oversedation. Oversedation may affect the systemic vascular resistance and cardiac output resulting in hypotension, which in turn causes slowing of the oxygen transport to the tissues. Oversedation may cause systemic hypotension due to decreased vascular resistance and diminished cardiac output, which by slowing the circulation give way to compromised tissue oxygen delivery and changes in the tissue oxygen consumption. ${ }^{11}$ Evidently, oversedation is a risk factor in the postoperative period; hence vital signs such as blood pressure, heart rate, breathing, besides oximetry, capnometry and level of consciousness must be monitored while the postoperative pain is being treated. ${ }^{11,12}$ This argument emphasizes the importance of pain control in decreasing the morbidity and mortality in the postoperative period.

Prior studies indicate that the great majority of the patients suffer from moderate to severe pain after surgery, which suggest that the health care personnel fail to control the postoperative pain effectively.1,8 Aslan and Badir, ${ }^{13}$ mention in their publication that $58 \%$ of the physicians and nurses fail to take appropriate countermeasures to prevent the postoperative pain due to their lack of knowledge, even though pain management clearly is an integral part of nursing care. ${ }^{14,15}$ The most important distinction is that the nurse, who is the key person in pain management, is in the position to spend a longer time with the patient. ${ }^{16}$ This unity with the patient enables the nurse a holistic approach to the pain management in terms of being acquainted with the patient's previous pain experience and coping skills; at the same time teaching the patient effective pain management methods, giving guidance, and implementing pain treatment plan, and documenting the outcome of the same. ${ }^{17,18}$

The effective postoperative pain management aims at minimizing or eliminating patient's discomfort due to pain, facilitating rapid recovery and returning to full function, reducing morbidity, limiting the hospital stay, and preventing recurrence of pain related problems. ${ }^{10}$ Postoperative pain management includes assessment of the pain, monitoring and correction of pain related complications, patient and family education, and documentation of the process to allow further reassessment of the pain management approaches. ${ }^{19}$

\section{ASSESSMENT OF THE PAIN}

In order to manage the postoperative pain effectively, the pain level must be measured appropriately. The goals of pain assessment are to determine the pain severity, help choose the analgesic dosage, which is appropriate to that particular level of pain, and document the effectiveness of pain treatment. Ideally, the patient is encouraged to actively participate in pain assessment, evaluation of pain regularly on a standard scale, and reassessment of the pain when an unexpected increase occurs. ${ }^{18,20}$

Pain assessment starts at the time of admission and should include an assessment of the patient's activities of daily living (ADL) and pain and stress coping skills. Patient's questions should be answered in order to better plan postoperative pain control strategies. In the postoperative period, it is important to assess the cause of pain (i.e. whether the patient's pain is related to the surgical incision, other surgical trauma or medical complications such as acute myocardial infaction). Since a patient's response to pain is specific to that person, pain should be evaluated individually. The issues that the nurse must pay attention when assessing the postoperative pain including the following: : $^{1020-22}$

- Assess pain both at rest and on movement to evaluate the patient's functional status.

- Take into consideration patient self-report of pain and implement the proper pain scale, document the intensity, quality, location, timing \& duration, aggravating and alleviating factors, and prior pain treatments and their effectiveness.

- The effect of a given treatment is evaluated by assessing pain before and after every treatment intervention.

- In the surgical Post Anesthesia Care Unit (PACU) or other circumstances where pain is intense, evaluate, treat, and re-evaluate frequently (e.g. every $15 \mathrm{~min}$ initially, then every $1-2 \mathrm{~h}$ as pain intensity decreases).

- On the surgical ward, evaluate, treat, and reevaluate regularly (e.g. every $4-8 \mathrm{~h}$ ) both the pain and the patient's response to treatment.

- Define the maximum pain score above which pain relief is offered (the intervention threshold). For example, verbal ratings score of 3 at rest and 4 on moving, on a 10-point scale.

- Patients who have difficulty communicating (e.g. cognitively impaired, children, and patients whose level of education or cultural background differs significantly from that of their health care team) their pain require particular attention. 
- Unexpected intense pain, particularly if associated with altered vital signs, (hypotension, tachycardia, or fever), is immediately evaluated.

- New diagnoses, such as wound dehiscence, infection, or deep venous thrombosis, should be considered. ate.

- Family members are involved when appropri-

- Document the pain assessment carefully.

- Report the results to the pain management team.

Studies indicate that the nursing assessment of postoperative pain management is inadequate; Ozer et al. ${ }^{15}$ report that $74.5 \%$ of the nurses do not use a pain scale when assessing patient's pain and $47.4 \%$ only observe patient's pain behavior rather than using any scale.

Sloman et al. ${ }^{21}$ point out that the pain scores documented by the nurses are significantly lower than the scores reported by the patients, which is consistent with results of Ahlers et al. ${ }^{23}$ Despite the focus on meeting standards of care in the area of postoperative pain management, there is an overwhelming lack of patient reassessment by nurses after the administration of analgesics. ${ }^{24}$

\section{TREATMENT OF THE PAIN}

Clinicians who care for patients have an ethical obligation to treatment postoperative pain and suffering using a combination of approaches pharmacological and non-pharmacological methods. ${ }^{25}$ Important aspects for pain are tabulated below: ${ }^{22,24}$

- Administer analgesics on "around the clock basis" not "as needed".

- Individualize the dosage.

- Because of short-term use, opioid addiction is not a concern in the postoperative period.

- Calculate the dosage based on the sedation level, respiratory status, preexisting conditions, opioid tolerance, and severity of the pain not on the duration of the pain.

- Utilize the most convenient route of administration.

- When using Patient Controlled Analgesia (PCA), explain the method and familiarize the patient with the device.

- Educate the patient about PCA. Routes of administration of PCA are varied such as oral, sublingual, subcutaneous, nasal, intramuscular, intravenous and epidural.
- Avoid using placebo because administering placebo may erode the trust relationship between the patient and the health care workers. ${ }^{26}$ Also, American Society for Pain Management Nursing (ASPM), ${ }^{26}$ American Pain Society, ${ }^{27}$ National Pharmaceutical Council and $\mathrm{JCl}$ have important position statements on the use of placebo drugs. ${ }^{26}$

The role of the nurse in control of postoperative pain also includes the following: ${ }^{17,29}$

- Administer pain medication in a timely manner before the scheduled painful procedures such as, dressing change, physical therapy etc.

- Monitor pain treatment outcome.

- Utilize of non-pharmacological means to make the pain tolerable.

- Provide a suitable calm environment for the patient.

- Eliminate other sources of discomfort, such as full bladder, infiltration of IV etc.

- Reposition the patient regularly to eliminate pressure sores and enhance circulation.

- Encourage patient to move extremities while in the bed because activity decreases muscle spasm and booster circulation.

Edwards et al. ${ }^{30}$ investigated nursing knowledge regarding opioid use in control of pain. This study comprising 800 nurses, points out that the nurses have several unsubstantiated negative opinions about opioids, which may cause failure of pain treatment. A study by Yava $^{31}$ investigating the effect of nursing procedures on postoperative patient outcome, showed that the nurses have incomplete knowledge, especially in the area of medications.

\section{MONITORING OF COMPLICATIONS}

Due to the fact that too high or too low blood levels of opioids may both result in complications, patients who are under treatment for pain need to be closely monitored. ${ }^{32,33}$ The expectation from nursing service in regard to monitoring of pain treatment related complications include the following: ${ }^{29}$

- Observation of side effects of pain treatment such as respiratory depression, oversedation, constipation).

- Certain opioids e.g. meperidine when administered in prolonged or high doses may cause muscle rigidity and seizures, which require close observation of the patient when such medications are used (i.e. for demeprol the usual dosage is $50 \mathrm{mg}$ to 150 mg orally, every 3 or 4 hours as necessary). 
- Certain patients such as with asthma, COPD, and other breathing problems may have respiratory depression and other side effects due to opioids, which again require careful monitoring.

- Naloxone should be readily available to treat respiratory depression for patients taking opioids.

The nurse, who is monitoring the side effects of the pain treatment, should be ready to recognize and correct the complications within the expected scope of nursing practice. For example, if respiratory depression develops in a patient receiving opioid infusion, the nurse is expected to stop the infusion, administer naloxone via an IV injection, keep the airway open, administer oxygen, and prepare to intubate. Meanwhile the physician is notified. All these procedures are carefully monitored and documented. ${ }^{19}$

\section{DOCUMENTATION OF DATA}

$\mathrm{JCl}$ mandates documentation of pain management approaches, including evaluation and reevaluation of the pain periodically. The documentation of postoperative pain includes assessment of the patient's pain, implementation of nursing measures to control the pain, and recording of the response of the patient to the treatment rendered. ${ }^{34}$ Studies indicate that nursing documentation of pain assessment is inadequate. ${ }^{34,35}$ Idvall and Ehrenberg ${ }^{34}$ reviewing 172 patient records, investigated nursing documentation in the postoperative period, which showed that in $50 \%$ and $89 \%$ of the cases nursing records did not document the location of pain and the quality of pain respectively.

Regular monitoring of the pain in the postoperative period enables early detection of complications. Documenting is useful for treatment, good communication between staff, auditing and quality control. ${ }^{10}$

\section{PATIENT AND FAMILY EDUCATION}

Successful pain management requires team effort, which includes the patient and the family. The American Pain Society recomends involving patients and families in pain management plan. ${ }^{32}$ Nurses should include the patient's family in the pain management procedure. Patient and the family should be educated in identifying, use of the pain scale, factors affecting the pain, pain treatment options, side effects of the treatment, and training required for the treatment such as use of PCA device. ${ }^{20,36,37}$ Cetin and Eser $^{2}$ published an article investigating the effects of patient education about the use of PCA devices in the postoperative pain control. This study showed that patients with training achieved better analgesic levels earlier, and used the PCA more effectively. This conclusion confirms the importance of patient and family education in postoperative pain control.

\section{EVALUATION OF THE PAIN MANAGEMENT}

The pain management procedure should be critically evaluated to assure that it fulfills its purpose, which requires answering certain questions: ${ }^{36,38}$

-What is the appropriate time interval between the treatments in the postoperative pain relief? According to Ferrell and McCaffery, ${ }^{39}$ when using morphine, peak effect is expected within 15 minutes after IV administration, ${ }^{30-45}$ minutes after IM administration, and 1.5-2 hours after oral administration after which pain should be reevaluated. Anyway, nurses should assess at peak effect but pain relief may take much longer and more doses to achieve.

- Did the pain diminish or stop altogether?

- Did the pain restart after a certain time?

- Did the pain actually stop, or lack of pain report is due to patient having difficulty expressing the pain?

Answering these questions assists the nurse in evaluating the effectiveness of the pain management strategies and the nursing interventions.

In conclusion, postoperative pain management is an integral part of nursing practice and thus, nurses should have a holistic approach to the postoperative care in order to improve the effectiveness of pain management. Thus, the nurse's responsibilities include the following: ensure the patient receives appropriate evidence-based nursing assessment and treatment, monitor the pain and pain treatment related complications, educate the patient and the family, document the steps of pain management, and meet the recognized standards of postoperative patient care.

\section{REFERENCES}

1. Chung JWY, Lui JCZ. Postoperative pain management: study of patients' level of pain and satisfaction with health care providers' responsiveness to their reports of pain. Nurse Health Sci 2003;5(1):13-21.

2. Cetin N, Eser I. Hasta kontrollü analjezi yöntemine ilişkin verilen hasta eğitiminin postoperatif ağrinin giderilmesine etkisinin incelenmesi. Ege Üniversitesi Hemşirelik Yüksek Okulu Dergisi 2006;22 (2):15-25.

3. Young L. Canadian Nurses' Pain Issues Working Group. 2006. Available at; http://www.fm-cfs.ca/PainAug162005.pdf. 
4. Joint Commission Requirements. 2007. Available at; http://www.jointcommission.org/AccreditationPrograms/ Office-BasedSurgery/ Standards/ standards_sampler. htm.

5. American Pain Society (APS). 2003. Pain: the fifth vital sign. Available at; http://www.ampainsoc.org/pub/bulletin/jan03/reso3.htm

6. Mularski RA, White-Chu F, Overbay D, Miller L, Asch SM, Ganzini L. Measuring pain as the $5^{\text {th }}$ vital sign does not improve quality of pain management. J General Int Med 2006;21(6):607-12.

7. Plaisance L, Logan C. Nursing student's knowledge and attitudes regarding pain. Pain Manag Nurs 2006;7(4):167-175.

8. Reimer-Kent J. Improving postoperative pain management by focusing on prevention. Nursing BC 2004;36(4):20-4.

9. Yegin A, Erdoğan A, Hadimoğlu N. Toraks cerrahisinde ameliyat sonrasi analjezi. Türk Göğüs Kalp Damar Cerrahisi Dergisi 2005;13(4):418-25.

10. Postoperative Pain Management Good Clinical Practice Available at; http://www.esraeurope.org/PostoperativePainManagement.pdf

11. Kaygusuz K, Gürsoy S, Kunt N, Kafalı H. Yoğun bakımda kullanılan sedatif ajanların hemodinami ve oksijen transportu üzerine etkileri. Erciyes Tıp Dergisi 2004; 26(4):165-77.

12. Richard N. Merchant. Special announcement: Guidelines to the practice of anesthesia. Can J Anesth 2010; 57(1):15-7.

13. Eti Aslan F, Badır A. Ağrı kontrol gerçeği: hemşirelerin ağrının doğası, değerlendirilmesi ve geçirilmesine ilişkin bilgi ve inançları. Ağrı 2005; 17(2): 44-51.

14. Wojahn A. 2006. Postoperative Care. Encylopedia of Nursing and Allied Health. Available at; http://findarticles.com/p/articles/mi_gGENH/is_/ai_2699003627 / pg_3?tag=artBody;col1

15. Özer $S$, Akyürek B, Başbakkal Z. Hemşirelerin ağri ile ilgili bilgi, davranişlari ve klinik karar verme yeteneklerinin incelenmesi. Ağrı 2006;18(4):36-43.

16. Bell L, Duffy A. Pain assessment and management in surgical nursing: a literature review. Br. J. Nurs 2009;18(3):153-6.

17. Pirbudak Çöçelli L., Bacaksız D. B., Ovayolu N. Ağrı Tedavisinde Hemşirenin Rolü. Gaziantep Tıp Dergisi 2008;14(1):53-58.

18. Mularski R, Puntillo K, Varkey B, et al. Pain management within the palliative and end-of-life care experience in the ICU. CHEST 2009;135:1360-1369 Available at; http://chestjournal.chestpubs.org/content/135/5/1360. full.html

19. Yüceer S. 2008. Hemşirelik öğrencilerinin beşinci yaşam belirtisi olan ağri ve ameliyat sonras ağrı yönetimine ilişkin bilgi düzeylerinin saptanması. Yükseklisans tezi, Ankara.

20. Anestezi Uygulama Klavuzları/Postoperatif Ağrı Tedavisi. 2006. Available at; http://www.tard.org.tr/kilavuz/7. pdf.
21. Sloman R, Rosen G, Rom M, Shir Y. Nurses' assessment of pain in surgical patients. J Adv Nurs 2005;52(2):12532.

22. Herr K, Coyne PJ, Key T et al. Pain assessment in the nonverbal patient: position statement with clinical practice. Pain Manag Nurs 2006;7(2): 44-52.

23. Ahlers SJGM, van Gulik L, van der Veen AM et al. Comparison of different pain scoring systems in critically ill patients in a general ICU. Crit. Care 2008;12(1):R15.

24. Bucknall T, Manias E, Botti M. Nurses' reassessment of postoperative pain after analgesic administration. Clin J Pain 2007;23(1):1-7.

25. Williams E. Nursing Perspective on pain management. Essentials of Pain Management 2011, Part 5, 367-377.

26. American Society for Pain Management Nursing (ASPMN) Position statement use of placebos in pain management. 2004. Available at; http://www.aspmn.org/ pdfs/Use\%20of\%20Placebos.pdf.

27. American Pain Society (APS). Position statement on the use of placebos in pain management. 2003. Available at; http://www.ampainsoc.org/advocacy/pdf/placebo. pdf.

28. National Pharmaceutical Council and Joint Commission on Accreditation of Healthcare Organizations. Pain: Current Understanding of Assessment, Management and Treatments. 2001. Available at; http://www.jcaho. org/news +room/health+care+issues/pain+mono_npc.

29. Degirmenci S.2006. Ağrı Kontrolu. Available at; http://www.anh.gov.tr/index.php?option=com_ docman\&task=doc_download\&gid=49\&ltemid=414

30. Edwards HE, Nash RE, Najman JM et al. Determinants of nurses' intention to administer opioids for pain relief. Nurs Health Sci 2001;3:149-159.

31. Yava A. 2004. Postoperatif Ağrı Tedavisinde Hemşirelik Uygulamalarının Etkinliği. Doktora tezi, GATA, Ankara.

32. American Pain Society Quality of Care Task Force. American Pain Society recommendations for improving the quality of acute and cancer pain management. Arch Intern Med 2005;165(10):1574-80.

33. Pasero C, Puntillo K, Li D et. al. Structured approaches to pain managementin the ICU. CHEST 2009;135(12):1665-72

34. Idvall E, Ehrenberg A. Nursing documentation of postoperative pain management. J Clin Nurs 2002;11(6):73442.

35. Dalton JA, Carlson J, Blau W. Documentation of pain assessment and treatment: How are we doing? Pain Manag Nurs 2001;2:54-64.

36. Sherwood GD, McNeill JA, Starck PL, Disnard G. Changing Acute Pain Management Outcomes In Surgical Patients. AORN J 2003;77(2):377-80.

37. Acute Pain Services Guidelines \& Protocols. 3rd edition; 2004. http://www.cuhk.edu.hk/med/ans/pain/APS guidelines.doc.

38. Dihle A, Bjolseth G, Helseth S. The gap between saying and doing in postoperative pain management. $\mathrm{J}$ Clin Nurs 2005;15(3):469-79.

39. Ferrell B, McCaffery M. 2005. Knowledge and Attitudes Survey Regarding Pain. Available at; http://prc.coh.org. 